\title{
Production and characterization of lyophilized powder of yellow mombin (Spondias mombin L.) and umbu (Spondias tuberosa)
}

\section{Polyana Barbosa da Silva ${ }^{1^{*}}$, Francisco de Assis Cardoso Almeida ${ }^{1}$, Josivanda Palmeira Gomes ${ }^{1}$, Semirames do Nascimento Silva ${ }^{1}$, Antonio Jackson Ribeiro Barroso ${ }^{1}$, Joselito de Sousa Moraes ${ }^{1}$, Luzia Márcia de Melo Silva ${ }^{2}$, Joana D'arc Paz de Matos ${ }^{1}$, Luis Paulo Firmino Romão da Silva ${ }^{1}$, Bruno Adelino de Melo ${ }^{1}$, Christiane Mendes Cassimiro Ramires ${ }^{3}$}

\author{
${ }^{1}$ Federal University of Campina Grande, Campus I, Campina Grande, PB, Brazil \\ ${ }^{2}$ Federal Institute of Education, Science, and Technology of Alagoas, Campus Murici, Murici, AL, Brazil \\ ${ }^{3}$ Paraiba Research, Rural Extension and Land Regularization Company, Brazil
}

*Corresponding author: polyana.silva@gmail.com;

ORCID: https://orcid.org/0000-0003-0205-7687

\begin{abstract}
Yellow mombin and umbu are appreciable fruits with growing demand in the Northeast region of Brazil, used mainly in the form of pulps, juices, and ice cream, having great economic potential. Lyophilized products have high added value for maintaining a good part of their nutritional characteristics. The objective was to produce and characterize yellow mombin and umbu powders by lyophilization, using different concentrations of maltodextrin. The pulps were prepared in five formulations considering the addition of maltodextrin, with $0,10,20,25$ and $30 \%$ for yellow mombin and $0,10,15,20$, and $30 \%$ for umbu. Then they were frozen and lyophilized in a model L101 lyophilizer at a pressure at a final pressure of $170 \mathrm{mmHg}$ and a temperature of $(-50 \cong \mathrm{C}+/-3$ oC). The physical-chemical characterization of the whole pulps and of the yellow mombin and umbu powders was carried out and were determined: water content (\%), $\mathrm{a}_{\mathrm{w}}$ (water activity), protein (\%), lipids (\%), ash (\%), ascorbic acid (mg of ascorbic acid.100g-1), SS (-Brix), pH, titratable acidity (\%), SS/AT ratio, color ( $\mathrm{L}^{*}, \mathrm{a}^{*}$ and $\left.\mathrm{b}^{*}\right)$, solubility (\%) and hygroscopicity (\%). Only in the formulation with $30 \%$ maltodextrin the water content of the powders was less than $5 \%$, as recommended by the legislation for lyophilized fruits. The lower water activity $\left(a_{w}\right)$ was also obtained in this formulation, in addition to increased solubility and reduced hygroscopicity, which are factors that favor the quality and conservation of powders, which are more suitable for the production of food products.
\end{abstract}

Keywords: drying; fruits; lyophilization; maltodextrin; physico-chemical analysis.

Abbreviations: $a_{w}$ _ Water Activity; $a^{*}$ _ Scale from green to red; $b^{*}$ _ Scale from blue to yellow; L*_Luminosity; CV_ Coefficient of variance; SS _ Soluble Solids; SS/TA_Soluble Solids/ Titratable Acidity; TA _ Titratable acidity.

Introduction

Fruit growing in Northeast Brazil is a promising economic activity, due to the exotic flavor and aroma of its fruits and its enormous diversification. The yellow mombin tree (Spondias mombin L.) is native to humid forests in much of northern South America, although it is uncertain whether the Atlantic Forest populations in Brazil are native; it is widely grown in tropical humid regions (Mitchell and Daly, 2015). Yellow mombin fruit is much appreciated and consumed in the Northeast region of Brazil, it has commercial value, and contributes to the income of small and medium producers in the region. It is consumed mainly in the form of pulps, juices, ice cream, and jams and has great economic and growth potential in the domestic and foreign markets. The umbu tree (Spondias tuberosa), a species native to the Brazilian semi-arid region, stands out for its socio-economic importance, providing fruits and tubers rich in water and nutrients, of multiple uses, in addition to leaves used as food for animals. Umbuzeiro fruits are harvested in an extractive manner and participate significantly in regional agribusiness, both in natura consumption and in processed form, being of great socioeconomic importance especially for rural populations in the Brazilian semi-arid region, with great potential for exploration (Batista et al., 2015). Powdered food products have been increasingly studied and developed, since they have characteristics such as high stability, thus extending their storage period, easy handling, and reduced transportation costs. Several fruit powder products have been developed and evaluated, such as orange pulp (Pacheco et al., 2019), noni juice (Zhang et al., 2020), guava juice (Benavides-Morán et al., 2020), pineapple juice (Jimenez-Sánchez et al., 2019), acerola and seriguela juice (Ribeiro et al., 2019). Various drying methods are used to obtain these powdered foods, among them, lyophilization. According to Orrego et al. (2008), lyophilization consists of a sublimation drying process in order to reduce losses of compounds responsible for the taste and aroma of food, which normally occurs during conventional drying processes. 
Vieira et al. (2012) state that lyophilized foods have high added value by retaining a large part of their nutrients since they use low temperatures in their processing.

To obtain powders for certain foods, it is necessary to use additives that assist in this process and maltodextrin is widely used in the industry. According to Damodaran et al. (2010), maltodextrins, as they are known industrially, are products obtained from the incomplete hydrolysis of dispersions of cooked starches, in the presence of acids or enzymes, then producing mixtures of maltooligosaccharides. These are classified according to their equivalence in dextrose (DE), which is their reducing power as a percentage of the reducing power of pure D-glucose (dextrose), and are measurable and less than 20. Maltodextrins are practically tasteless and are excellent contributors to the body and the volume of food systems. Given the above, the objective of this work was to produce and characterize yellow mombin and umbu powder by lyophilization, using different concentrations of maltodextrin.

\section{Results and Discussion}

\section{Physico-chemical characterization of yellow mombin and umbu pulps}

Table 1 shows the average values of the physical-chemical characteristics obtained in the yellow mombin pulp. The water content of the pulp was lower than that reported by Sousa et al. (2016) who found values of $89.02 \%$ for yellow mombin pulp. For water activity, these authors obtained a value of 0.98 , similar to that obtained in this work.

The amount of protein, lipids and ash were higher than those presented in the Brazilian Food Composition Table (Taco, 2011), which is $0.6 \%, 0.2 \%$ and $0.4 \%$, respectively. According to Taco, the frozen yellow mombin pulp contains only traces of vitamin $\mathrm{C}$, and the evaluated yellow mombin pulp showed $8.82 \mathrm{mg}$ of ascorbic acid. $100 \mathrm{~g}^{-1}$ of pulp. The ascorbic acid content varies according to the conditions of cultivation, storage and processing, and can be used as an index of food quality (Chitarra and Chitarra, 2005).

Rodrigues et al. (2018) evaluating the quality of yellow mombin fruits reported SS content of $15.42 \%$ and acidity

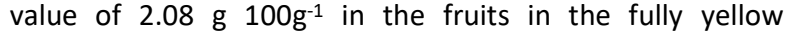
maturation stage, classified according to the color of the peel, being these superior to those obtained in the evaluated pulp. Carvalho et al. (2017) determined in 17 yellow mombin matrix $\mathrm{pH}$ values of the pulp varying between 2.26 and 2.93 and acidity between 1.08 and 1.78 (\% citric acid), with the value obtained in the yellow mombin pulp evaluated in present work within these ranges. The same authors obtained an average value of 8.50 for the SS / TA ratio, lower than the value obtained in the yellow mombin pulp, a higher SS / TA ratio consists of a determining factor in the quality of pulps, favoring the consumption of fresh fruit or processed.

The average value of luminosity $\left(L^{*}\right)$ was higher than those determined by Sousa et al. (2017) in six samples of yellow mombin pulp in which the values varied between 35.10 and 47.31 , the authors obtained for $a^{*}$ values ranging from 5.46 to 8.46 and for $b^{*}$ values between 18.44 and 28.90 , much lower than those obtained in this work, where the pulps were revealed with colorings tending to more intense red and yellow. Color is an important quality attribute in products intended for processing, its intensity is important in juices because it is more attractive to the consumer (Chitarra and Chitarra, 2005). Table 2 shows the average values of the physicochemical characteristics of the umbu pulp. The water content was lower than that obtained by Silva et al. (2018) whose content was $89.46 \%$ and the water activity similar to that obtained by Carvalho et al. (2015) in umbu pulps (0.99). These results were compatible with this type of product. The protein content obtained was the same as that presented in Taco (2011), which is $0.50 \%$ and slightly lower than that reported by Bastos et al. (2016) for commercial umbu pulp, whose value was $0.68 \%$. The lipid content obtained was higher than that contained in Taco (2011), which is $0.1 \%$ and lower than that determined by Ribeiro et al. (2019) in fresh umbu pulp, whose value was $6.00 \%$, the authors reported a value of 2.21 for ashes, which is higher than that of the pulp evaluated. The ascorbic acid content obtained was lower than that reported by Bastos et al. (2016) when characterizing pulp of commercial umbu, whose value was $5.47 \mathrm{mg} 100 \mathrm{~g}^{-1}$, the authors obtained an average soluble solids value of 8.5 Brix and a $\mathrm{pH}$ of 2.42 , which are lower than those obtained in the assessed umbu pulp. Dutra et al. (2017) reported values of soluble solids ranging from 6.27 to $10.22^{\circ}$ Brix and pH from 2.34 to 2.40 in umbu fruits, lower than those determined in the pulp characterized in this work, these same authors also obtained average acidity values ranging from 1.84 to $2.91 \%$, also lower than the value obtained for the umbu pulp evaluated. The SS / TA ratio in the umbu pulp was low, but higher than the values obtained by Lima et al. (2018) in three umbu pulp brands, which were 1.42, 1.43 and 1.71. Usually the acidity of fruits is reduced with ripening and the SS / TA ratio is one of the most used ways to evaluate the taste, being more significant than the isolated measurement of sugars or acidity (Chitarra and Chitarra, 2005). Santos et al. (2017) when evaluating umbu pulp at different maturation stages, reported an $L^{*}$ value of 41.17 in the mature stage, lower than that determined in umbu pulp, which revealed a lighter shade. At the same stage of maturation, the authors determined values of $a^{*}$ and $b^{*}$ of -2.27 and 24.70, respectively, with $a^{*}$ being superior and $b^{*}$ inferior to the value determined in the pulp evaluated in this work, in which the green color predominated.

\section{Physico-chemical characterization of lyophilized yellow mombin and umbu pulp powders with different concentrations of maltodextrin}

Table 3 shows the average values of the physico-chemical characteristics of the yellow mombin pulp powders obtained by lyophilization and formulated with different concentrations of maltodextrin. The water content decreased by $77.51 \%$ with the increase in the concentration of maltodextrin in the concentration of $30 \%$ compared to the powder without the additive, reaching a value below $5 \%$ and complying with the legislation for lyophilized fruits (Brasil, 1978). Oliveira et al. (2014) when characterizing yellow mombin powders obtained by lyophilization, obtained average water contents of 2.05 and $0.65 \%$ in the whole yellow mombin powder and in the added powder of $17 \%$ of maltodextrin, respectively, lower than those obtained in the present work, this difference may have occurred due to the amount of material used in the equipment, or even by its model and capacity. Sousa et al. (2016) reported an average value of $5.85 \%$ in powdered yellow mombin pulp obtained by lyophilization formulated with $25 \%$ maltodextrin, slightly higher than that determined in this work at the same concentration. These authors obtained $a_{w}$ values of 0.30 in the poder of the whole 
Table 1. Average values of the physical-chemical characteristics in the yellow mombin pulp.

\begin{tabular}{|lll|}
\hline Evaluated parameters* & Means and standard deviation & CV (\%) ${ }^{1}$ \\
\hline Water content (\%) & $86.84 \pm 0.11$ & 0.12 \\
\hline $\mathrm{a}_{\mathrm{w}}$ & $0.986 \pm 0.00$ & 0.06 \\
\hline Protein (\%) & $0.84 \pm 0.01$ & 1.47 \\
\hline Lipids (\%) & $0.41 \pm 0.02$ & 4.33 \\
\hline Ash (\%) & $0.59 \pm 0.02$ & 3.10 \\
\hline Ascorbic acid (mg of ascorbic acid.100 ${ }^{-1}$ ) & $8.82 \pm 0.05$ & 0.51 \\
\hline SS ( ${ }^{\circ}$ Brix) & $11.2 \pm 0.20$ & 1.79 \\
\hline pH & $2.93 \pm 0.01$ & 0.20 \\
\hline Titratable acidity (\% citric acid) & $1.09 \pm 0.01$ & 0.97 \\
\hline SS/TA & $10.27 \pm 0.22$ & 2.16 \\
\hline L $^{*}$ & $54.47 \pm 0.07$ & 0.13 \\
\hline $\mathrm{a}^{*}$ & $24.66 \pm 0.08$ & 0.30 \\
\hline $\mathrm{b}^{*}$ & $54.10 \pm 0.09$ & 0.17 \\
\hline
\end{tabular}

Note. ${ }^{*}$ The data are means of three replicates \pm Standard Deviation. ${ }^{1-C o e f f i c i e n t ~ o f ~ v a r i a n c e ; ~} a_{w}$ - Water Activity; SS - Soluble Solids; SS/TA- Soluble Solids/ Titratable Acidity; L* - Luminosity; $\mathrm{a}^{*}$ - Scale from green to red; $\mathrm{b}^{*}$ - Scale from blue to yellow.

Table 2. Average values of the physical-chemical characteristics in the umbu.

\begin{tabular}{|c|c|c|}
\hline Evaluated parameters* & Means and standard deviation & CV $(\%)^{1}$ \\
\hline Water content (\%) & $88.05 \pm 0.76$ & 0.86 \\
\hline$a_{w}$ & $0.99 \pm 0.00$ & 0.00 \\
\hline Protein (\%) & $0.50 \pm 0.02$ & 3.13 \\
\hline Lipids (\%) & $0.26 \pm 0.01$ & 4.63 \\
\hline Ash (\%) & $0.41 \pm 0.01$ & 1.41 \\
\hline Ascorbic acid (mg of ascorbic acid.100g-1) & $2.86 \pm 0.08$ & 2.72 \\
\hline $\mathrm{SS}\left({ }^{\circ}\right.$ Brix $)$ & $10.73 \pm 0.12$ & 1.08 \\
\hline $\mathrm{pH}$ & $2.93 \pm 0.06$ & 2.08 \\
\hline Titratable acidity (\% citric acid) & $3.93 \pm 0.10$ & 2.58 \\
\hline SS/TA & $2.73 \pm 0.09$ & 3.15 \\
\hline$L^{*}$ & $54.44 \pm 0.02$ & 0.04 \\
\hline a* & $-6.74 \pm 0.20$ & 3.01 \\
\hline$b^{*}$ & $30.44 \pm 0.16$ & 0.51 \\
\hline
\end{tabular}

Note. ${ }^{*}$ The data are means of three replicates \pm Standard Deviation. ${ }^{1-C o e f f i c i e n t}$ of variance; $\mathrm{a}_{\mathrm{w}}$ - Water Activity; SS - Soluble Solids; SS/TA- Soluble Solids/ Titratable Acidity; L* - Luminosity; $\mathrm{a}^{*}$ - Scale from green to red; $\mathrm{b}^{*}$ - Scale from blue to yellow.

Table 3. Average values of the physico-chemical characteristics of the yellow mombin powders with different concentrations of maltodextrin.

\begin{tabular}{|c|c|c|c|c|c|c|}
\hline \multirow[t]{2}{*}{ Evaluated parameters } & \multicolumn{6}{|c|}{ Concentrations of maltodextrin (\%) } \\
\hline & 0 & 10 & 20 & 25 & 30 & $\mathrm{CV}(\%)^{1}$ \\
\hline Water content (\%) & 18.99 a & $11.57 \mathrm{~b}$ & $7.09 \mathrm{c}$ & $5.33 \mathrm{~d}$ & $4.27 \mathrm{e}$ & 3.04 \\
\hline$a_{w}$ & $0.38 \mathrm{a}$ & $0.34 \mathrm{a}$ & $0.37 \mathrm{a}$ & $0.19 \mathrm{~b}$ & $0.12 \mathrm{c}$ & 6.39 \\
\hline Protein (\%) & $6.29 \mathrm{a}$ & $3.52 \mathrm{~b}$ & $2.44 \mathrm{c}$ & $2.42 \mathrm{c}$ & $1.76 \mathrm{~d}$ & 5.83 \\
\hline Lipids (\%) & $2.03 \mathrm{a}$ & $1.99 \mathrm{a}$ & $1.29 \mathrm{~b}$ & $1.22 \mathrm{~b}$ & $1.47 \mathrm{~b}$ & 9.37 \\
\hline Ash (\%) & $3.05 \mathrm{a}$ & $1.98 \mathrm{~b}$ & $1.56 \mathrm{~cd}$ & $1.71 \mathrm{c}$ & $1.50 \mathrm{~d}$ & 3.51 \\
\hline $\begin{array}{l}\text { Ascorbic acid (mg of ascorbic } \\
\text { acid. } 100 \mathrm{~g}^{-1} \text { ) }\end{array}$ & $34.01 \mathrm{~b}$ & $43.61 \mathrm{a}$ & $34.59 \mathrm{~b}$ & $34.19 \mathrm{~b}$ & $30.76 \mathrm{~b}$ & 4.85 \\
\hline $\mathrm{pH}$ & 2.90 & 2.93 & 2.97 & 3.00 & 3.03 & - \\
\hline Titratable acidity (\% citric acid) & $6.91 \mathrm{a}$ & $4.05 \mathrm{c}$ & $3.20 \mathrm{~d}$ & $4.64 \mathrm{~b}$ & $4.12 \mathrm{c}$ & 1.22 \\
\hline$L^{*}$ & $61.26 \mathrm{e}$ & $65.62 \mathrm{~d}$ & $70.85 c$ & $73.39 \mathrm{~b}$ & $74.62 \mathrm{a}$ & 0.38 \\
\hline a* & $19.66 \mathrm{a}$ & $17.23 \mathrm{~b}$ & $14.16 \mathrm{c}$ & $13.05 \mathrm{~d}$ & $12.40 \mathrm{e}$ & 0.47 \\
\hline$b^{*}$ & $62.47 \mathrm{a}$ & $57.58 \mathrm{~b}$ & $50.66 \mathrm{c}$ & $43.57 \mathrm{~d}$ & $41.66 \mathrm{e}$ & 0.31 \\
\hline Solubility (\%) & $73.13 c$ & $75.28 c$ & $80.71 \mathrm{~b}$ & $81.64 \mathrm{~b}$ & $86.39 \mathrm{a}$ & 1.97 \\
\hline Hygroscopicity (\%) & $27.49 \mathrm{a}$ & $21.45 \mathrm{~b}$ & $18.74 \mathrm{c}$ & $16.09 \mathrm{~d}$ & $16.45 \mathrm{~d}$ & 0.84 \\
\hline
\end{tabular}

${ }^{1-C o e f f i c i e n t ~ o f ~ v a r i a n c e ; ~} a_{w}$ - Water Activity; $L^{*}$ - Luminosity; $a^{*}$ - Scale from green to red; $b^{*}$ - Scale from blue to yellow. Means followed by the same letter in the line do not differ by Tukey's test at $5 \%$ probability level. 
Table 4. Average values of physicochemical characteristics of post umbu with different types of maltodextrin

\begin{tabular}{|c|c|c|c|c|c|c|}
\hline \multirow[t]{2}{*}{ Evaluated parameters } & \multicolumn{6}{|c|}{ Concentrations of maltodextrin (\%) } \\
\hline & 0 & 10 & 15 & 20 & 30 & $\mathrm{CV}(\%)^{1}$ \\
\hline Water content (\%) & $16.50 \mathrm{a}$ & $8.99 \mathrm{~b}$ & $8.14 \mathrm{bc}$ & $5.35 \mathrm{bc}$ & $3.39 \mathrm{c}$ & 21.11 \\
\hline$a_{w}$ & $0.32 \mathrm{a}$ & $0.29 \mathrm{~b}$ & $0.32 \mathrm{a}$ & $0.31 \mathrm{a}$ & $0.07 \mathrm{c}$ & 1.90 \\
\hline Protein (\%) & $6.59 \mathrm{a}$ & $3.99 \mathrm{~b}$ & $2.17 \mathrm{c}$ & 0.87 e & $1.50 \mathrm{~d}$ & 4.86 \\
\hline Lipids (\%) & $1.19 \mathrm{a}$ & $0.92 \mathrm{~b}$ & $0.77 \mathrm{bc}$ & $0.87 \mathrm{bc}$ & $0.67 c$ & 10.24 \\
\hline Ash (\%) & $2.71 \mathrm{a}$ & $1.64 \mathrm{~b}$ & $1.63 \mathrm{~b}$ & $1.40 \mathrm{~b}$ & $1.02 \mathrm{c}$ & 5.41 \\
\hline Ascorbic acid (mg of ascorbic acid.100g ${ }^{-1}$ ) & $16.92 \mathrm{a}$ & $15.02 \mathrm{a}$ & $9.05 \mathrm{~b}$ & $7.91 \mathrm{~b}$ & $4.52 \mathrm{c}$ & 7.34 \\
\hline $\mathrm{pH}$ & 2.77 & 2.87 & 2.91 & 2.95 & 3.04 & - \\
\hline Titratable acidity (\% citric acid) & $9.15 \mathrm{a}$ & $5.71 \mathrm{~b}$ & $4.25 \mathrm{c}$ & $4.14 \mathrm{c}$ & $3.24 \mathrm{~d}$ & 0.81 \\
\hline$L^{*}$ & $65.39 \mathrm{e}$ & $70.71 \mathrm{~d}$ & $72.60 \mathrm{c}$ & $74.51 \mathrm{~b}$ & $90.14 \mathrm{a}$ & 0.30 \\
\hline$a^{*}$ & $6.50 \mathrm{a}$ & $3.70 \mathrm{~b}$ & $2.90 \mathrm{c}$ & $2.59 \mathrm{~d}$ & $-3.36 \mathrm{e}$ & 0.90 \\
\hline$b^{*}$ & $39.08 \mathrm{a}$ & $31.36 \mathrm{~b}$ & $29.91 \mathrm{c}$ & $27.45 d$ & $19.43 \mathrm{e}$ & 0.52 \\
\hline Solubility (\%) & $75.30 \mathrm{~b}$ & $80.33 \mathrm{a}$ & $81.77 \mathrm{a}$ & $83.38 \mathrm{a}$ & $82.44 \mathrm{a}$ & 2.06 \\
\hline Hygroscopicity (\%) & $18.74 \mathrm{a}$ & $18.71 \mathrm{a}$ & $17.61 \mathrm{~b}$ & $16.63 \mathrm{c}$ & $14.90 \mathrm{~d}$ & 1.42 \\
\hline
\end{tabular}

1-Coefficient of variance; $a_{w}$ - Water Activity; $L^{*}$ - Luminosity; $a^{*}$ - Scale from green to red; $b^{*}$ - Scale from blue to yellow. Means followed by the same letter in the line do not differ by Tukey's test at $5 \%$ probability level.

yellow mombin pulp, lower than that obtained in the powder with $0 \%$ maltodextrin, and $0.28,0.26$ and 0.20 in the powders formulated with 15,20 and $25 \%$ of maltodextrin, respectively, the latter being close to that obtained in the yellow mombin pulp at the same concentration. There was no statistical difference in the $a_{w}$ values in the powders formulated with 0,10 , and $20 \%$ of maltodextrin, and in the concentrations of 25 and $30 \%$, there was a reduction in the values. The $a_{w}$ values remained below 0.6 , which is the limiting $a_{w}$ value for microbial development (Franco and Landgraf, 2005).

There was a concentration of protein, lipid, and ash contents in the lyophilization process which, with the addition of maltodextrin, are reduced, but remained higher than those of fresh pulp (Table 1). The ash contents were higher than those reported by Sousa et al. (2016) who obtained $0.65 \%$ in lyophilized whole yellow mombin pulp and $0.59,0.48$, and $0.37 \%$ in lyophilized yellow mombin powders formulated with 15, 20 and $25 \%$ maltodextrin respectively. The higher ash content in the lyophilized whole pulp in the present work suggests that the analyzed material has a higher mineral content. The ascorbic acid content was also concentrated in the lyophilization process; however there was no statistical difference with the addition of the drying aid, with the exception of the $10 \%$ concentration of maltodextrin.

Oliveira et al. (2014) reported $\mathrm{pH}$ values of 2.65 and 2.63 in the powder of the whole yellow mombin pulp and added $17 \%$ maltodextrin, respectively, being lower than those obtained in this work in all the evaluated yellow mombin powders. For acidity, the authors obtained a value of $9.11 \%$ in the whole pulp powder, higher than that obtained in the yellow mombin powder without the additive and $3.18 \%$ in the one with $17 \%$ of maltodextrin, close to that obtained in the yellow mombin powder with $20 \%$.

The lyophilization process and the addition of maltodextrin resulted in an increase in $L^{*}$, the values obtained from powders with maltodextrin being higher than those determined by Freitas et al. (2018) when evaluating yellow mombin powder obtained by drying in a foam layer at four temperatures where they obtained values of $63.02,64.93$, 45.56 and 45.61 at temperatures of $50,60,70$ and 80 ㅇ, respectively, observing, therefore, that the drying process used by the authors resulted in darker pulps as the applied temperature increased. These authors observed an increase in the values of $a^{*}$ and a reduction in the values of $b^{*}$ with the increase in the drying temperature, reaching, respectively, 15.90 and 29.73 at the temperature of $80 \stackrel{\circ}{\circ}$. In the powders evaluated in the present work, there was a reduction in the value of $a^{*}$ and an increase in the value of $b^{*}$ with the lyophilization process without the use of the additive, however, with the addition of maltodextrin, there was a reduction in the values of these parameters in which the powders lost a little yellow tint.

The average values of solubility increased gradually with the concentration of maltodextrin, reaching $86.39 \%$ when adding $30 \%$ of the drying aid, an increase of $18.13 \%$ when compared to the powder without additive. Hygroscopicity decreased with the addition of the drying aid, reaching a reduction of $59.84 \%$ in the powder formulated with $30 \%$ maltodextrin, not differing, however, from the powder with $25 \%$ of the additive, in these concentrations of maltodextrin the powder is considered hygroscopic oaccording to the classification of Gea Niro Research Laboratory (2003), in which the reference value used is $15.1-20$. Solubility and hygroscopicity are parameters of great importance for powder products since it directly determines and influences the quality and functionality of this type of product.

Table 4 shows the average values of the physicochemical characteristics of the umbu pulp powders obtained by lyophilization formulated with different concentrations of maltodextrin.

The water content of the umbu powder obtained from the formulation with $30 \%$ maltodextrin did not differ from the formulations with 15 and $20 \%$ and it suffered a reduction of $79.45 \%$ compared to the formulation without the additive. Only in the powder formulated with $30 \%$ of the additive, water content of less than $5 \%$ was obtained, a value established by the legislation for lyophilized fruits (Brasil, 1978). Souza et al. (2020) evaluating powdered umbu juice using spray dryer drying and 10-DE maltodextrin in different drying conditions obtained water contents ranging from $2.05 \%$ to $4.32 \%$, with the content obtained in umbu powder with $30 \%$ of maltodextrin within this range. The authors obtained values for water activity ranging from 0.12 to 0.23 , lower than those obtained in umbu powders in all formulations except for the $30 \%$ one, whose value was 0.07 . With the use of the additive, there was a reduction in $a_{w}$, with the formulation with $30 \%$ differing statistically from the others. The powders showed $a_{w}$ values below 0.6 , which is 
the limiting $a_{w}$ value for microbial development (Franco and Landgraf, 2005), being safe for consumption.

The levels of protein, lipids, ash, and ascorbic acid also decreased with the addition of maltodextrin, but the average values of these parameters in all formulations remained higher than in the whole pulp (Table 2). Barroso et al. (2017) reported in lyophilized umbu pulp with $20 \%$ maltodextrin contents of $4.70 \%$ proteins, higher than the value obtained in umbu powder evaluated at the same concentration, and $0.82 \%$ lipids and $1.35 \%$ of ash, which are inferior to those obtained in the umbu powder evaluated in this work at the same concentration as the additive. The same authors obtained ascorbic acid contents of 22.66 mg. $100 \mathrm{~g}^{-1}$ (mg of ascorbic acid in 100g) in lyophilized umbu powders with $20 \%$ maltodextrin, which is higher than the value obtained for the umbu powder evaluated at this same concentration. Even with the reduction in the levels of ascorbic acid caused, probably, by the addition of maltodextrin, the powder with $30 \%$ of the additive still presented a higher content of this constituent when compared to the whole pulp.

The $\mathrm{pH}$ values increased with the increase in the concentration of the drying aid and the acidity decreased significantly, however in the concentrations of 15 and $20 \%$ of the additive the values did not differ statistically. Carvalho et al. (2017) evaluating umbu-cajá powder made with umbucajá pulp, goat milk and different concentrations of maltodextrin by spray dryer obtained $\mathrm{pH}$ values ranging from 3.15 to 3.20 , lower than those obtained for umbu powder evaluated. These authors obtained an acid value of 4.56 in the powder formulated with $10 \%$ maltodextrin and values ranging from 3.84 to 3.92 with $20 \%$, lower than those obtained in umbu powders at the same concentrations of maltodextrin. Conegero et al. (2017) reported a pH value of 3.12 in mangaba pulp powder formulated with $30 \%$ maltodextrin, higher than that determined in umbu pulp powder formulated with the same concentration of the additive and titratable acidity of $3.04 \%$, a little lower.

The luminosity values $\left(L^{*}\right)$ increased with the use of the additive, making the powders lighter, with a statistical difference between the averages. The average value of the pulp powder without maltodextrin was lower than that reported by Santos et al. (2016) in umbu-cajá pulp powders obtained by lyophilization using 10, 20 and 30\% gum arabic in the formulation of the pulp whose values were 76.36, 78.23 and 80.14, respectively, which are lower than determined in umbu powder formulated with $30 \%$ maltodextrin. The same authors reported for the pulp powder of umbu-cajá formulated with $30 \%$ gum arabic values of 4.68 and 25.31 for $a^{*}$ and $b^{*}$, respectively, higher than the values obtained in umbu powder with $30 \%$ maltodextrin, whose values of $a *$ and $b *$ decreased with the additive making the color of the powders with a tendency towards green color and occurring the loss of yellow color.

The solubility of the powders increased with the increase in the concentration of maltodextrin, however, there was no difference between the formulations containing the additive, however, compared to the powder without the additive, the increase was $9.48 \%$ in the powder with $30 \%$ maltodextrin. The average values of hygroscopicity decreased with the increase in the concentration of maltodextrin, however, there was no statistical difference between the powder obtained from the whole pulp and the pulp powder added with $10 \%$ of the additive, only the values of the average of the powders obtained from formulations with 15, 20 and 30\% differed statistically. Souza et al. (2020) reported hygroscopicity values varying between 13.62 and $22.92 \%$ in powdered umbu juices by spray dryer using $10-D E$ maltodextrin and different drying conditions. The values obtained in the evaluated umbu powders are in this range. At a concentration of $30 \%$ of maltodextrin, the powder showed hygroscopicity below $15 \%$ and it is considered a slightly hygroscopic product, according to the classification by Gea Niro Research Laboratory (2003).

\section{Materials and methods}

\section{Plant materials}

Yellow mombin (Spondias mombim L.) - The fruits, at the stage of commercial maturation, were purchased from a producer in João Pessoa - Paraíba, Brazil through a partnership with the Paraiba Company of Research, Rural Extension and Land Regularization (EMPAER). They were packed in thermal boxes and transported to the Food Processing Laboratory of the Center for Technology and Regional Development (CTDR) of the Federal University of Paraíba (UFPB). They were selected, washed and sanitized in chlorinated water at a dilution of 200 ppm for a period of ten min, with subsequent rinsing and pulped in a stainless steel pulping machine. Then, the pulps were packed in polyethylene packaging and frozen until the moment of use. Umbu (Spondias tuberosa) - Umbu pulps purchased from a cooperative located in the municipality of Afogados de Ingazeira, Pernambuco, Brazil were used.

\section{Obtention of lyophilized powders}

The collection of powders and the characterization of pulps and powders were carried out at the Agricultural Products Storage and Processing Laboratory (LAPPA) at the Federal University of Campina Grande (UFCG). Initially, the whole pulps were evaluated for physical-chemical parameters. Then, they were prepared in five formulations regarding the addition of the maltodextrin 20-DE drying adjuvant, in which the percentages of $0,10,20,25$, and $30 \%$ were used for the yellow mombin pulp and $0,10,15,20$ and $30 \%$ for the umbu pulp. The formulated pulps were accommodated in plastic polyethylene forms and frozen for $24 \mathrm{~h}$, then transferred to aluminum trays and frozen again in a freezer at $-18^{\circ} \mathrm{C}$ for 72 $h$ and then subjected to the lyophilization process for a period of $72 \mathrm{~h}$, being carried out in a model L101 lyophilizer at a pressure at a final pressure of $170 \mathrm{mmHg}$ and a temperature of $(-50 \stackrel{\circ}{\circ}+/-3 \stackrel{\circ}{\circ})$ under vacuum. The powders were packed in laminated packaging and stored at room temperature until the time of physical-chemical analysis to choose the best formulation for obtaining the powders.

\section{Characterization of the yellow mombin and umbu pulps and powders with different concentrations of maltodextrin}

The water content was determined by directly drying in an oven at 105 oc, using $5 \mathrm{~g}$ of sample for pulp and $2 \mathrm{~g}$ of sample for powder, the protein content was determined by the Kjeldahl method and the ash content was determined in a muffle at 550 으, according to Brasil (2008). The water activity $\left(a_{w}\right)$ was obtained by direct reading on the AquaLab model 3TE equipment, with a controlled temperature of $25.0 \pm 0.5^{\circ} \mathrm{C}$. The determination of the lipid content was carried out using the methodology described by Bligh and Dyer (1959). The ascorbic acid content was determined according to the methodology described in AOAC (2010), 
modified by Benassi and Antunes (1998). The Soluble Solids (SS) content was determined through a refractometer "WYA Abbe Refractometer" (check) coupled with a temperature of $20^{\circ} \mathrm{C}$, according to AOAC (2010). The hydrogen potential $(\mathrm{pH})$ was measured using a digital potentiometer and the titratable acidity (TA) determined by titration according to Brazil (2008). The SS / TA Ratio were obtained through the reasoning of the SS to AT indices (Chitarra and Chitarra, 2005). The color was measured in a MiniScan HunterLab XE Plus colorimeter, with the determination in $\mathrm{CIE} \mathrm{L}^{*}$, $\mathrm{a}^{*}$ and $\mathrm{b}^{*}$ mode, in which the $L^{*}$ value corresponds to luminosity, how light and how dark the analyzed product is, the a* corresponds to the scale from green to red and the value of $b^{*}$ corresponds to the scale from blue to yellow. The solubility of the powders was determined according to the methodology described by Dacanal and Menegalli (2009). The hygroscopicity of the powders was determined according to the method proposed by Goula and Adamopoulos (2010).

\section{Statistical analysis}

A completely randomized design composed of five treatments was used, with concentrations of maltodextrin of $0,10,20,25$, and $30 \%$ for the yellow mombin pulp and 0,10 , 15,20 , and $30 \%$ for the umbu pulp, using 3 repetitions per treatment. The data submitted to analysis of variance and the averages compared by the Tukey test at $5 \%$ probability using the computer program Assistant version 7.7 beta (Silva and Azevedo, 2016).

\section{Conclusion}

Yellow mombin and umbu powders formulated with 30\% maltodextrin proved to be more suitable for the formulation and production of food products, the water contents were below $5 \%$ only in this concentration, as recommended by the legislation for lyophilized fruits. The lowest water activity was also obtained in powders with $30 \%$ maltodextrin, this parameter being of fundamental importance in their storage and conservation. The increase in solubility and the reduction in hygroscopicity also contribute to the quality and conservation of the powders, with a concentration of $30 \%$ being the most favorable to these factors. The powders of yellow mombin and umbu fruits can be used as ingredients in the formulation of food as mixes or in the reconstitution of fruit juices, the formulation with $30 \%$ maltodextrin being the most suitable for this purpose.

\section{References}

Aoac. Association of Official Analytical Chemists (2010) Official Methods of Analysis. 18a. ed $3^{\underline{a}}$ Review. Washington: USA

Barroso AJR, Almeida FAC, Silva LMM (2017) Desenvolvimento de mixes com extrato em pó de amendoim despeliculizado: $\mathrm{mix}$ de amendoim com mangaba e mix de amendoim com umbu. 1. ed. Beau Bassin: Novas Edições Acadêmicas.

Bastos JS, Martinez EA, Souza SMA (2016) Características físico-químicas da polpa de umbu (Spondias tuberosa Arruda Câmara) comercial: efeito da concentração. J Bioen Food Sci. 3: 11-16

Batista FRC, Silva SM, Santana MFS, Cavalcante AR (2015) O umbuzeiro e o Semiárido brasileiro. Campina Gramde, PB: INSA - Instituto do Semiárido Brasileiro.
Benassi MT, Antunes AJ (1998) A comparison of metaphosphoric and oxalic acids as extractant solutions for the determination of vitamin $\mathrm{C}$ in selected vegetables. Arq Biol Tecnol. 31: 507-513.

Benavides-Morán A, Cubillos A, Gómez, A (2020) Spray drying experiments and CFD simulation of guava juice formulation. Drying Technol. 38: 1-16.

Bligh EG, Dyer WJ (1959) A rapid method of total lipid extraction and purification. Can J Biochem Physiol. 37: 911-917.

Brasil. Ministério da Saúde. Agência Nacional de Vigilância Sanitária (1978) Resolução - CNNPA nํ12, de 24 de Julho de 1978. Normas Técnicas Especiais Relativas a Alimentos e Bebidas. Diário Oficial [da] Republica Federativa do Brasil, Brasília, DF.

Brasil. Ministério da Saúde. Agência Nacional de Vigilância Sanitária (2008) Métodos químicos e físico-químicos para análises de alimentos. Brasília: Ministério da Saúde.

Chitarra MI, Chitarra AB (2005) Pós-colheita de frutos e hortaliças: fisiologia e manuseio. 2. ed. rev. e ampl. Lavras: UFLA.

Carvalho AV, Nogueira, JG, Mattietto RA (2015) Elaboração e caracterização de estruturados de umbu. 1ạ edn, Embrapa Amazônia Oriental, Pará. 26.

Carvalho AV, Chaves RPF, Alves RM (2017) Caracterização física e físico-química de frutos em matrizes de cajazeira no estado do Pará. 1a edn, Embrapa Amazônia Oriental, Pará. 22.

Carvalho CM, Figueirêdo RMF, Queiroz AJM, Gurjão FF (2017) Caracterização do pó de umbu-cajá com leite de cabra e maltodextrina obtido pelo método de secagem em spray dryer. Tecnol Ciên Agropec. 11: 37-42.

Conegero J, Ribeiro LC, Costa JMC, Monteiro ARG (2017) Stability of 'mangaba' pulp powder obtained by freeze drying. Rev Bras Eng Agríc Amb. 21: 645-650.

Dacanal GC, Menegalli FC (2009) Experimental study and optimization of the agglomeration of acerola powder in a conical fluid bed. Powder Technol. 188: 187-194.

Damodaran S, Parkin KL, Fennema OR (2010) Química de Alimentos de Fennema. Trad. Brandelli et al. 4 ed. Porto Alegre: Artmed.

Dutra FV, Cardoso AD, Morais OM, Viana AES, Melo TL, Cardoso Júnior N S (2017) Características físicas e químicas de acessos de umbuzeiros (Spondias tuberosa Arr. Cam). Revista de Ciências Agrárias. 40: 814-822.Franco BDGM, Landgraf M (2005) Microbiologia dos alimentos. São Paulo: Atheneu.

Freitas BSM, Cavalcante MD, Cagnin C, Silva RMda, Plácido GR, Oliveira, DECde (2018) Physical-chemical characterization of yellow mombin (Spondias mombin L.) foam-mat drying at different temperatures. Rev Bras Eng Agríc Amb. 22: 430-435.

GEA Niro Research Laboratory. Gea Niro analytical methods 2003.

Goula AM, Adamopoulos KG (2010) A new technique for spray drying orange juice concentrate. Innovat Food Science Emerg Technol. 11: 342-351.

Jimenez-Sánchez DE, Calderón-Santoyo M, Herman-Lara $E$, Gaston-Peña C, Luna-Solano G, Ragazzo-Sánchez JA (2019) Use of native agave fructans as stabilizers on physicochemical properties of spray-dried pineapple juice. Drying Technol. 38: 293-303.

Lima LLA, Silva AMOE, Ferreira IM, Nunes TP, Carvalho MG (2018) Néctar misto de umbu (Spondias tuberosa Arr. Câmera) e mangaba (Hancornia Speciosa Gomes): 
elaboração e avaliação da qualidade. Braz J Food Technol. Campinas, 21: 1-8.

Mitchell JD, Daly DC (2015) A revision of Spondias L. (Anacardiaceae) in the Neotropics. PhytoKeys, 55: 1-92.

Oliveira GS, Costa JMC, Afonso MRA (2014) Caracterização e comportamento higroscópico do pó da polpa de cajá liofilizada. Rev Bras Eng Agríc Amb. 18: 1059-1064.

Orrego ACE (2008) Congelación y Liofilización de Alimentos. 1 ed. Manizales, Caldas, Colombia.

Pacheco C, García-Martínez E, Moraga G, Piña J, Nazareno MA, Martínez-Navarrete N (2019) Development of dried functional foods: Stabilization of orange pulp powder by addition of biopolymers. Powder Technol. 362: 11-16.

Ribeiro CMCM, Magliano LCSA, Costa MMAde, Bezerra TKA, Silva FLHda, Maciel MIS (2019) Optimization of the spray drying process conditions for acerola and seriguela juice mix. Food Sci Technol. 39: 48-55.

Rodrigues ENS, Silva SM, Bulhões TL, Melo RS, Sousa ASB, Lima RP, Mendonça RMN (2018) Mudanças na qualidade durante a maturação de frutos de cajazeiras. Revista Agropecuária Técnica. 39: 254-263.

Santos EHF, Figueiredo Neto A, Donzeli VP (2016) Aspectos físico-químicos e microbiológicos de polpas de frutas comercializadas em Petrolina (PE) e Juazeiro (BA). Braz J Food Technol. 19: 1-9.

Santos RTS, Lima AS, Castro CDPC, Rybka ACP, Assis JS, Biasoto ACT (2017) Avaliação físico-química da polpa de umbu em diferentes estádios de maturação. Trabalho apresentando no XX Encontro Nacional e VI Congresso Latino Americano de Analistas de Alimentos, Hangar Convenções \& Feiras da Amazônia, Belém, de 13 a 16 de agosto de 2017.
Silva FAS, Azevedo CAV (2016) The Assistat software version 7.7 and its use in the analysis of experimental data. Afr J Agric Res. 11: 3733-3740.

Silva ASda, Santana LRRde, Bspo ES, Lopes MV (2018) Use of Umbu (Spondias tuberosa arr. Camara) pulp for preparation of diet cereal bar. Rev Bras Frutic, Jaboticabal. 40 (2): 1-11.

Sousa FC, Silva LMM, Castro DS, Moreira IS, Rocha APT (2016) Caracterização do cajá in natura, formulado e liofilizado. Trabalho apresentado no III Congresso Técnico Científico da Engenharia e da Agronomia, Rafain Palace Hotel \& Convention Center, Foz do Iguaçu, 29 de agosto a 1 de setembro de 2016.

Sousa AS, Soares KMP, Góis VA, Freire BCF (2017) Qualidade microbiológica e físico-química de polpas de umbu-cajá e cajá comercializadas em Mossoró, RN. Higiene Alimentar. 31: 42-46.

Souza MMB, Santos AMP, Converti A, Maciel MIS (2020) Optimisation of umbu juice spray drying, and physicochemical, microbiological and sensory evaluation of atomised poder. J Microencapsulation. 37: 230-241.

Taco. Tabela Brasileira de Composição de Alimentos (2011) 4 ed. revisada e ampliada. Campinas, SP: UNICAMP.

Vieira AP, Nicoleti JF, Telis VRN (2012) Liofilização de fatias e abacaxi: avaliação da cinética de secagem e da qualidade do produto. Braz J Food Technol. 15: 50-58.

Zhang C, Ada Khoo SL, Chen XD, Quek SY (2020) Microencapsulation of fermented noni juice via micro-fluidic-jet spray drying: Evaluation of powder properties and functionalities. Powder Technol. 361: 9951005. 